\title{
Synthesis, Characterization and Antimicrobial Studies of Salicylic Acid Complexes of Some Transition Metals
}

\author{
${ }^{1}$ S. G. Yiase, ${ }^{2}$ S. O. Adejo*, ${ }^{3}$ J. A. Gbertyo and ${ }^{4}$ J. Edeh \\ ${ }^{1,2,3,4}$ Department of Chemistry, Benue State University, Makurdi
}

\begin{abstract}
Salicylic acid complexes of $\mathrm{Mn}^{2+}, \mathrm{Fe}^{2+}, \mathrm{Co}^{2+}, \mathrm{Ni}^{2+}$, and $\mathrm{Cr}^{3+}, \mathrm{Mn}^{3+}, \mathrm{Fe}^{3+}, \mathrm{Co}^{3+}$ metal ions were synthesized in ethanol solution. It was observed that the divalent ions gave better yield than the trivalent ones. The complexes were characterized on the basis of the following properties: solubility, electrical conductivity, FTIR and UV-visible spectrophotometry to determine the mode of binding of the ligand to each of the metal ions. The complexes were found to be slightly soluble in distilled water, but soluble in polar organic solvents, an indication that they are molecular compounds. However, their low conductivity values signify nonelectrolytic nature of the compounds. The shifting of the band at $1689.70 \mathrm{~cm}^{-1}$ to lower values in all the complexes and the vibration centered around $3522.13 \mathrm{~cm}^{-1}$ assigned to $v(\mathrm{OH})$ indicate that the carboxylic and the hydroxyl groups were involved in coordination to the metal ion, implying that the ligand is bidentate. Inhibition properties of the complexes against three fungi showed that the complexes have higher antimicrobial activity than the ligand which could be attributed to chelation. It appeared that the antifungal activity increased with decrease in ionic size. Their anti-fungi activities were, however, lower than that of a standard antifungal drug, griesifulvin.
\end{abstract}

Keywords: Salicylic acid, Salicylic acid complexes, Synthesis, Characterization, Antimicrobial studies

\section{Introduction}

Recent researches have shown significant progress in the utilization of transition metal complexes as drugs for treatment of several human disorders like cancer, lymphomas, infections, inflammation, diabetes and neurological disorders, amongst others [1,2]. For example, pepto-bismol (bismuth subsalicylate) has been found to be very effective in the control of nausea, heart burn, stomach upset and diarrhea [3] and cisplatin [cisdiammine-dichloroplatinum (II)] for the treatment of tumors [1]. Inorganic metal complexes like platinum (II) porphirins, titanocenedichloride, ruthenium (III) imidazole, ferrocenes and many organometallic analogues exhibit anti-cancer activity [1,4-6]. Silver (I) sulfadiazine, an anti-bacterial metal complex is effective in the treatment of severe burns. Manganese complexes have been screened against a number of pathogenic fungi and bacteria with most of them showing better sensitivity than the ligands $[1,2,7]$. Iron (III) complexes of quinoline have also proved useful in treatment of malaria $[1,8]$. Transition metal complexes have also been used as antiinflammatory and anti-arthritic agents, examples like sodium aurothiomalate, aurothioglucose and aurothiopropanol are all gold complexes. Complexes of copper and iron are capable of catalyzing dismutation of the superoxide anion [1]. Manganese (II) complex of biscyclohexylpyridine substituted macrocyclic ligand has been used to treat cell and tissue oxidative injuries by acting as superoxide anion scavenger [1,9]. Vanadium and chromium complexes significantly relieve glycaemia among patients with diabetes [10].

In this work we report the synthesis, characterization and antimicrobial activity of salicylic acid complexes of some transition metals, viz: $\mathrm{Mn}^{2+}, \mathrm{Mn}^{3+}, \mathrm{Fe}^{2+}, \mathrm{Fe}^{3+}, \mathrm{Co}^{2+}, \mathrm{Co}^{3+}, \mathrm{Ni}^{2+}$ and $\mathrm{Cr}^{3+}$ ions. This is in furtherance of the sustained interest in the utilization of the transition metal complexes in the treatment of human ailments, against the backdrop of the alarming problems of multi-drug resistant microorganisms, world over.

\section{Experimental}

\subsection{Materials and methods}

The salicylic acid complexes of the following transition metal salts were prepared using the method reported elsewhere [11, 12]: Chromium (III) chloride, $\mathrm{CrCl}_{3} \cdot 6 \mathrm{H}_{2} \mathrm{O}$; Manganese (II) chloride, $\mathrm{MnCl}_{2}$; Manganese

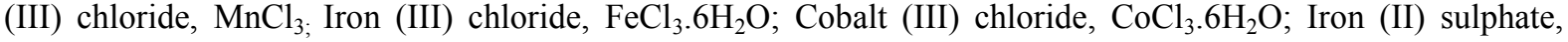
$\mathrm{FeSO}_{4} .7 \mathrm{H}_{2} \mathrm{O}$; Cobalt (II) chloride, $\mathrm{CoCl}_{2} \cdot 6 \mathrm{H}_{2} \mathrm{O}$; Nickel (II) chloride, $\mathrm{NiCl}_{2} \cdot 4 \mathrm{H}_{2} \mathrm{O}$. The melting points of the complexes were determined using Electro-thermal IA 92000 digital melting point apparatus, while solubility was determined in the following solvents: methanol, ethanol and distilled water. The complexes were further 
characterized using the Shimadzu FTIR-8400S Infrared Spectrophotometer, Jenway-6305 UV-Visible Spectrophotometer and WTW Conductometer. Thereafter, their antifungal activities were tested against a standard antifungal drug, griesifulvin.

\subsection{Preparation of the complexes}

\subsubsection{Preparation of $\mathrm{M}^{2+}$ salicylate complexes}

$2.760 \mathrm{~g}$ of the salicylic acid was dissolved in $20 \mathrm{~mL}$ of ethanol. The resulting solution was added to $1.259 \mathrm{~g}$ of manganese (II) chloride in $20 \mathrm{~mL}$ distilled water and then refluxed for 2 hours. The precipitate formed was filtered off, washed with ethanol and dried in a desiccator over anhydrous calcium chloride for one week. The same procedure was repeated using $2.779 \mathrm{~g}$ of iron (II) sulphate, $2.379 \mathrm{~g}$ of cobalt (II) chloride and $2.016 \mathrm{~g}$ of nickel (II) chloride [ 13, 14-15].

\subsubsection{Preparation of $\mathrm{M}^{3+}$ salicylate complexes}

$3.036 \mathrm{~g}$ of the salicylic acid was dissolved in $20 \mathrm{~mL}$ of ethanol. The resulting solution was added to $2.665 \mathrm{~g}$ of chromium (III) chloride in $20 \mathrm{~mL}$ distilled water and refluxed for 2 hours. The precipitate formed was filtered off, washed with ethanol and dried in a desiccator over anhydrous calcium chloride for one week. The same was repeated using $1.614 \mathrm{~g}$ of manganese (III) chloride, $2.704 \mathrm{~g}$ of iron (III) chloride, and $2.734 \mathrm{~g}$ of cobalt (III) chloride [13, 15-17].

\section{Results and Discussion}

Table 1 shows the physical characteristics of the ligand and the metal complexes.

Table 1.Characteristics of the ligand and metal complexes

\begin{tabular}{lclllccc}
\hline Sample & $\begin{array}{c}\text { Product yield } \\
(\%)\end{array}$ & Colour & $\begin{array}{c}\text { M.P } \\
\left({ }^{\circ} \mathrm{C}\right)\end{array}$ & $\begin{array}{l}\text { Physical } \\
\text { Appearance }\end{array}$ & $\begin{array}{c}\text { Conductivity } \\
\mu \mathrm{S} / \mathrm{cm}\end{array}$ & $\begin{array}{c}\lambda_{\max } \\
(\mathrm{nm})\end{array}$ & $\begin{array}{l}\text { IR } \\
v(C=O) \mathrm{cm}^{-1}\end{array}$ \\
\hline Salicylic acid & - & White & $157-159$ & Powdery & - & 340 & 1689.70 \\
{$\left[\mathrm{Cr}(\mathrm{sal})_{3}\right]$} & 42.64 & Green-white & $217-219$ & Crystalline & 91.3 & 345 & 1668.48 \\
{$\left[\mathrm{Mn}(\mathrm{sal})_{2}\right]$} & 60.27 & White & $220-222$ & Crystalline & 44.5 & 335 & 1666.55 \\
{$\left[\mathrm{Mn}(\mathrm{sal})_{3}\right]$} & 59.23 & White & $224-226$ & Crystalline & 71.9 & 335 & 1669.45 \\
{$\left[\mathrm{Fe}(\mathrm{sal})_{2}\right]$} & 68.85 & Reddish-brown & $186-189$ & Crystalline & 13.6 & 340 & - \\
{$\left[\mathrm{Fe}(\mathrm{sal})_{3}\right]$} & 55.89 & Brown & $189-190$ & Crystalline & 121.0 & 335,555 & 1666.55 \\
{$\left[\mathrm{Co}(\mathrm{sal})_{2}\right]$} & 53.19 & Pinkish-Blue & $208-210$ & Crystalline & 59.2 & 335 & 1677.16 \\
{$\left[\mathrm{Co}(\mathrm{sal})_{3}\right]$} & 72.36 & Pink & $13-215$ & Crystalline & 36.5 & 335 & 1675.23 \\
{$\left[\mathrm{Ni}(\mathrm{sal})_{2}\right]$} & 72.36 & Light-yellow & $220-223$ & Crystalline & 187.4 & 330 & 1668.48 \\
\hline
\end{tabular}

- $\quad$ M. $\mathrm{P}$ is melting point

The absorption bands below were observed from the spectra of the acid and its complexes (Figures 1 to 9)
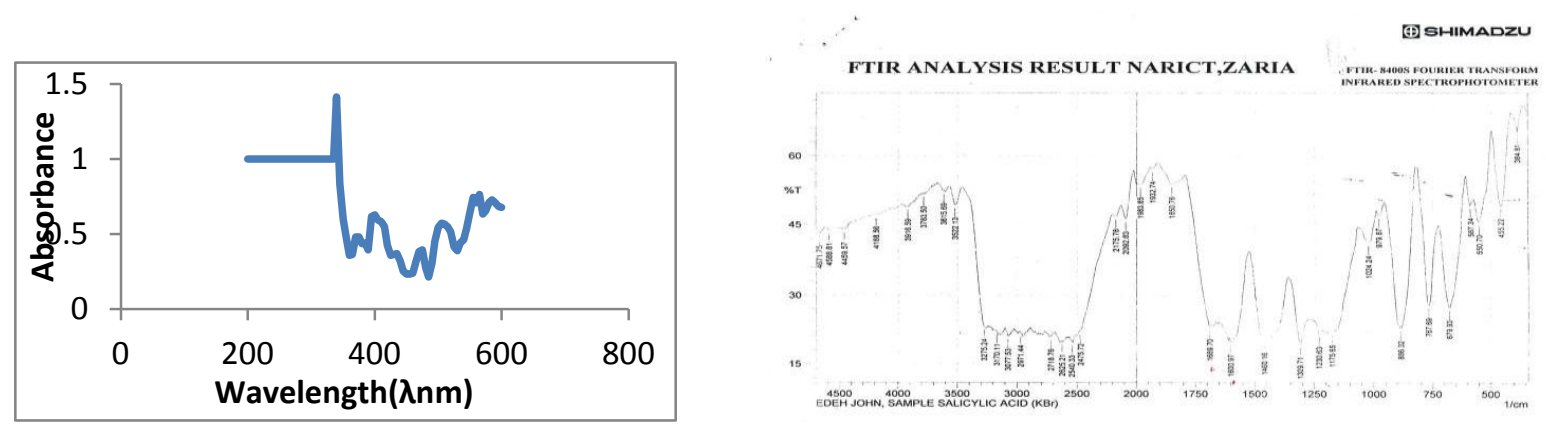
Fig. 1a UV spectrum for salicylic acid

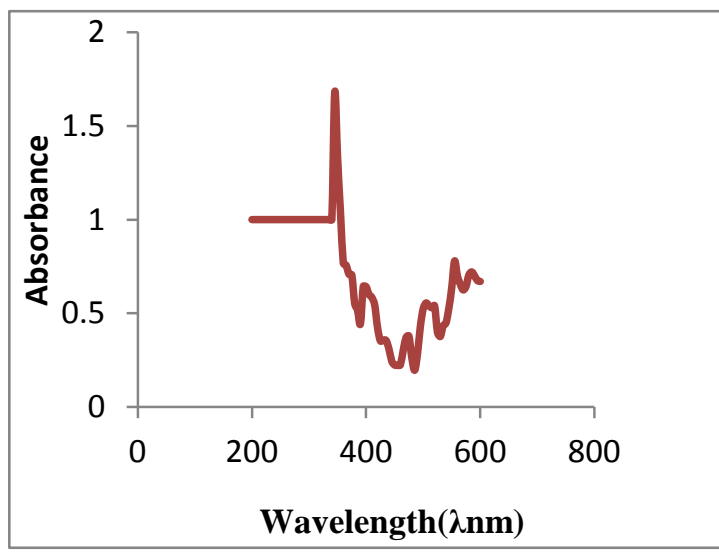

Fig. 2a UV spectrum for chromium (III) salicylate

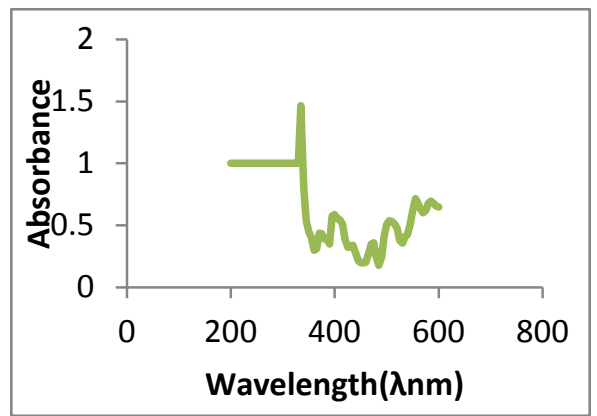

Fig. 3a UV Spectrum for manganese (II) salicylate

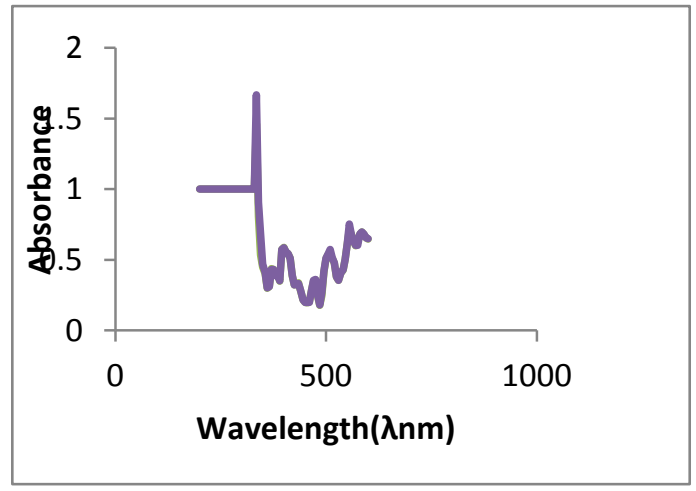

Fig. 4a UV Spectrum for manganese (III) salicylate
Fig. 1b FTIR spectrum for salicylic acid

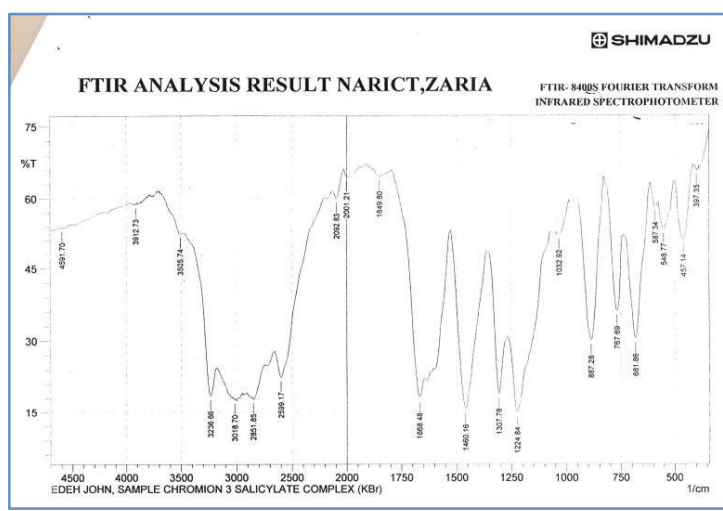

Fig. 2b FTIR spectrum for chromium (III) salicylate complex

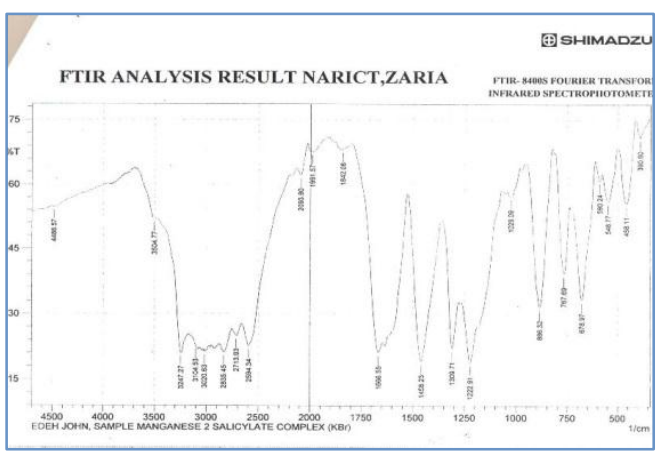

Fig. 3b FTIR Spectrum for manganese (II) salicylate complex

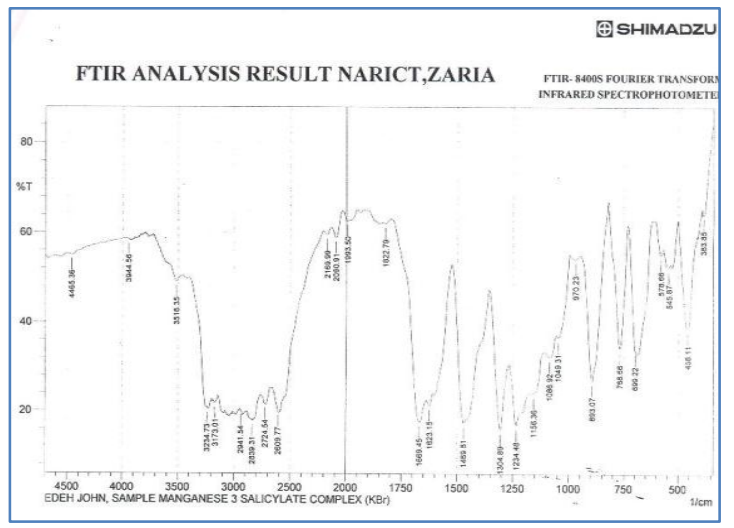

Fig. 4b FTIR Spectrum for manganese (III) salicylate complex 


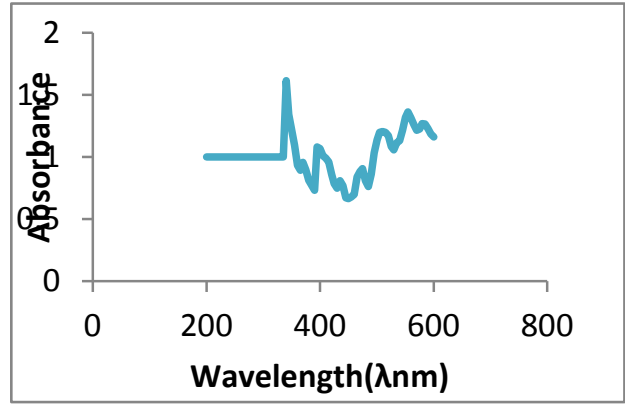

Fig 5a UV spectrum for iron (II) salicylate

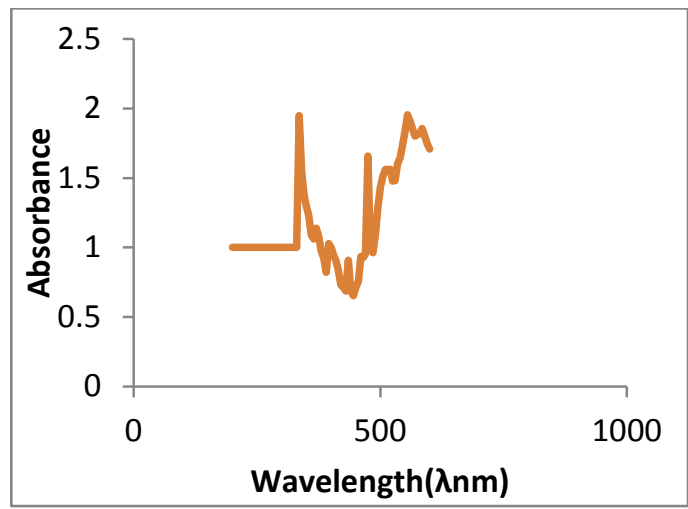

Fig. 6a UV spectrum for iron (III) salicylate

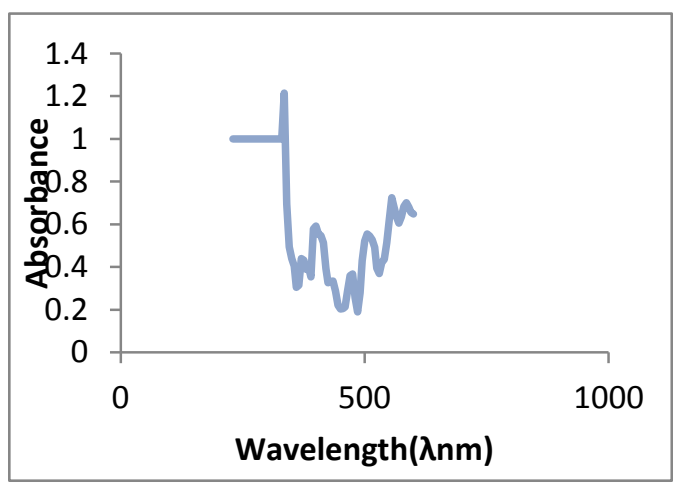

Fig. 7a UV spectrum for cobalt (II) salicylate

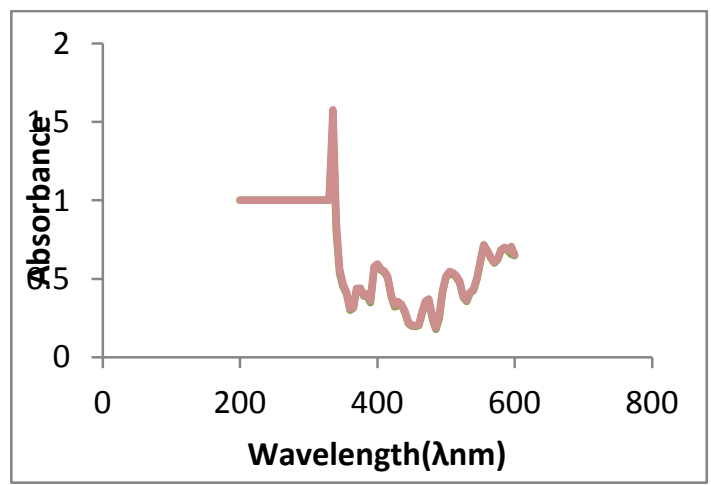

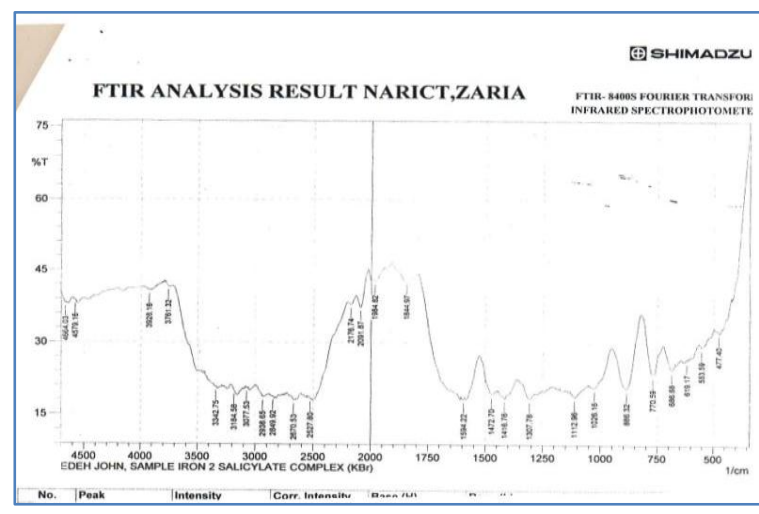

Fig $5 b$ FTIR spectrum for iron (II) salicylate

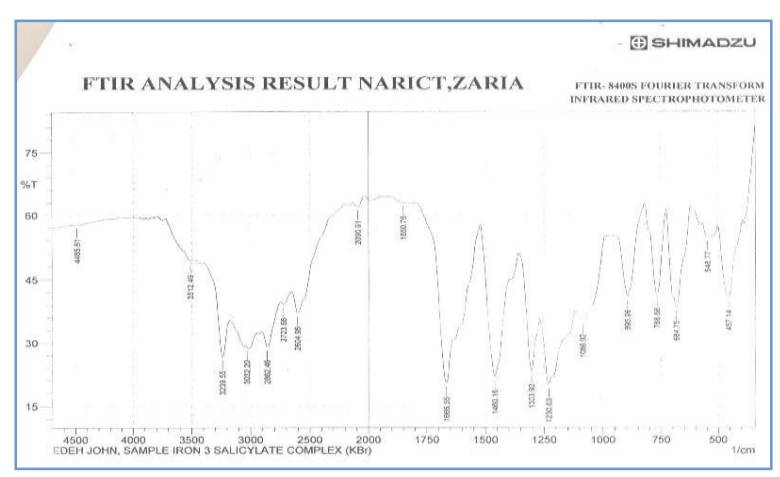

Fig. 6b FTIR spectrum for iron (III) salicylate complex

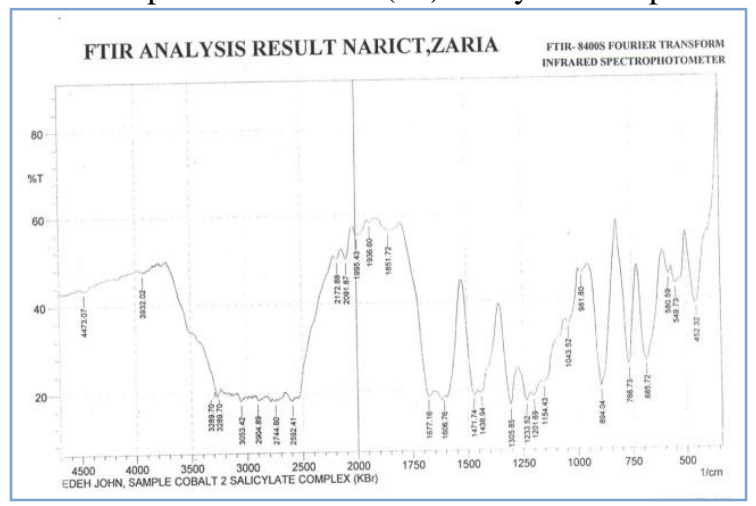

Fig. 7b UV spectrum for cobalt (II) salicylate complex

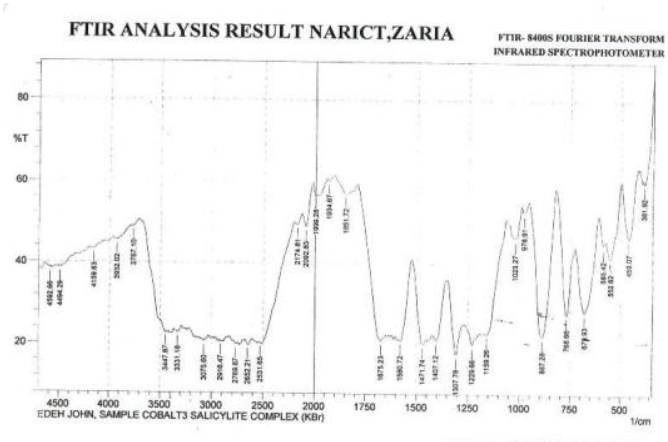


Fig. 8a UV spectrum for cobalt (III) salicylate

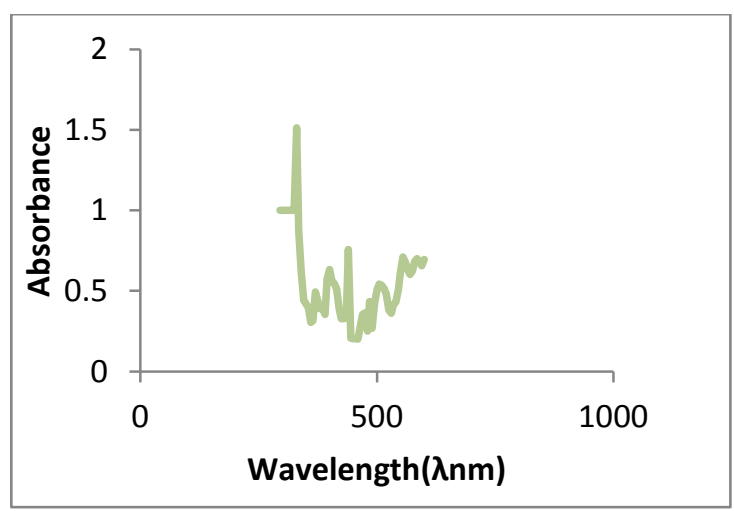

Fig. 9a UV spectrum for nickel (II) salicylate
Fig. 8b FTIR spectrum for cobalt (III) salicylate

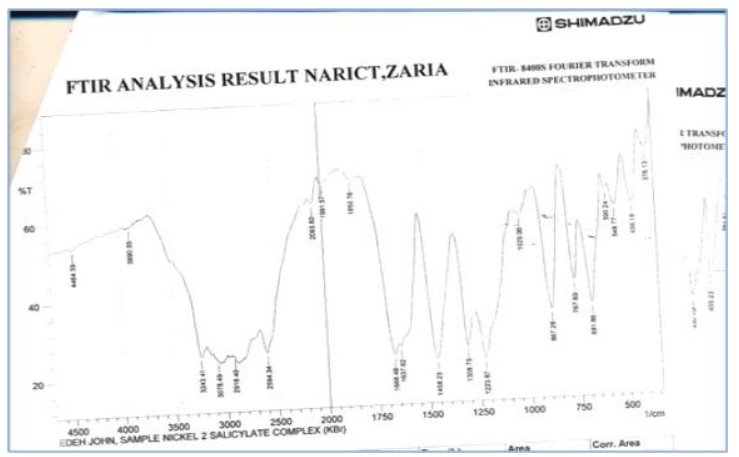

Fig. 9 FTIR spectrum for nickel (II) salicylate

Table 2. Solubility of the ligand and metal complexes in different solvents and their conductivities in acetone

\begin{tabular}{ccccc}
\hline Ligand/ Complex & $\begin{array}{c}\text { Distilled } \\
\text { water }\end{array}$ & Ethanol & Methanol & $\begin{array}{c}\text { Conductivity } \\
\mu \mathrm{S} / \mathrm{cm}\end{array}$ \\
\hline Salicylic acid & $\mathrm{NS}$ & $\mathrm{S}$ & $\mathrm{S}$ & - \\
{$\left[\mathrm{Cr}(\mathrm{sal})_{3}\right]$} & $\mathrm{SS}$ & $\mathrm{S}$ & $\mathrm{S}$ & 91.30 \\
{$\left[\mathrm{Mn}(\mathrm{sal})_{2}\right]$} & $\mathrm{SS}$ & $\mathrm{S}$ & $\mathrm{S}$ & 44.50 \\
{$\left[\mathrm{Mn}(\mathrm{sal})_{3}\right]$} & $\mathrm{SS}$ & $\mathrm{S}$ & $\mathrm{S}$ & 71.9 \\
{$\left[\mathrm{Fe}(\mathrm{sal})_{2}\right]$} & $\mathrm{SS}$ & $\mathrm{S}$ & $\mathrm{S}$ & 13.60 \\
{$\left[\mathrm{Fe}(\mathrm{sal})_{3}\right]$} & $\mathrm{SS}$ & $\mathrm{S}$ & $\mathrm{S}$ & 121.0 \\
{$\left[\mathrm{Co}(\mathrm{sal})_{2}\right]$} & $\mathrm{SS}$ & $\mathrm{S}$ & $\mathrm{S}$ & 59.20 \\
{$\left[\mathrm{Co}(\mathrm{sal})_{3}\right]$} & $\mathrm{SS}$ & $\mathrm{S}$ & $\mathrm{S}$ & 36.50 \\
{$\left[\mathrm{Ni}(\mathrm{sal})_{2}\right]$} & $\mathrm{SS}$ & $\mathrm{S}$ & $\mathrm{S}$ & 187.4 \\
\hline
\end{tabular}

The reduction in the frequency of $v(C=O)$ vibrational band were expected outcomes if the complexes were generated. The assignment and interpretation of vibrations below $1500 \mathrm{~cm}^{-1}$ are difficult to make with certainty because they occur in the finger print region where coupled vibrations occur. Metal-ligand vibrations are mostly observed below $800 \mathrm{~cm}^{-1}[18,19]$.

Based on the data generated from ultra violet and infrared specrtrophotometric analyses the following structures (fig. 1 and 2 below) were proposed.

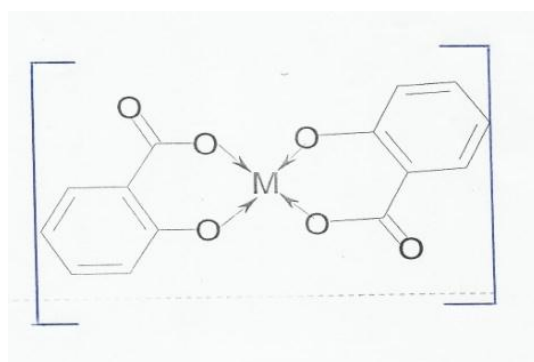

Fig. 1 Structure of $M^{2+}$ salicylate complex

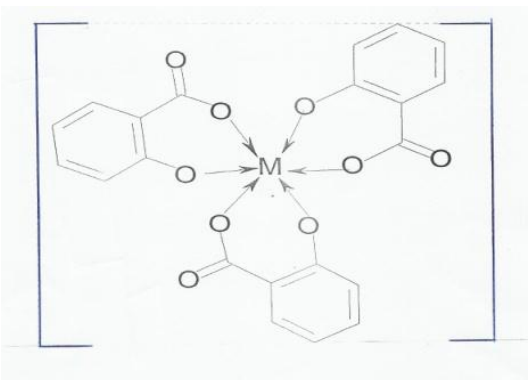

Fig. 2 Structure of $M^{3+}$ salicylate complex 
$\mathrm{M}^{2+}=\mathrm{Mn}^{2+}, \mathrm{Fe}^{2+}, \mathrm{Co}^{2+}$ and $\mathrm{Ni}^{2+}$

$$
\mathrm{M}^{3+}=\mathrm{Cr}^{3+}, \mathrm{Mn}^{3+}, \mathrm{Fe}^{3+} \text { and } \mathrm{Co}^{3+}
$$

The above structures were proposed based on the conditions of the following reactions:

$$
\begin{aligned}
& \mathrm{M}^{2+}+2 \mathrm{Sal}^{-} \rightarrow\left[\mathrm{M}(\mathrm{Sal})_{2}\right] \\
& \mathrm{M}^{3+}+3 \mathrm{Sal}^{-} \rightarrow\left[\mathrm{M}(\mathrm{Sal})_{3}\right]
\end{aligned}
$$

The antifungal activity of the metal salicylate complexes against the fungi at concentration of $100 \mathrm{mg} / \mathrm{mL}$ is given in Table 3. All the synthesized complexes showed comparative good activity against the fungi. The activity, however, follows the order: $\mathrm{Co}^{2+}>\mathrm{Co}^{3+}>\mathrm{Fe}^{3+}>\mathrm{Fe}^{2+}>\mathrm{Ni}^{2+}>\mathrm{Mn}^{2+}>\mathrm{Mn}^{3+}>\mathrm{Cr}^{3+}$ for Aspergillus ninger of which $\mathrm{M}^{2+}$ showed the order $\mathrm{Co}^{2+}>\mathrm{Fe}^{2+}>\mathrm{Mn}^{2+}>\mathrm{Ni}^{2+}$ and $\mathrm{M}^{3+}$ showed the trend $\mathrm{Co}^{3+}>$ $\mathrm{Fe}^{3+}>\mathrm{Mn}^{3+}>\mathrm{Cr}^{3+}$. Aspergillus hereus had the trend: $\mathrm{Co}^{2+}>\mathrm{Co}^{3+}>\mathrm{Ni}^{2+}>\mathrm{Fe}^{3+}>\mathrm{Fe}^{2+}>\mathrm{Mn}^{3+}>\mathrm{Cr}^{3+}>\mathrm{Mn}^{2+}$ with $\mathrm{M}^{2+}$ of the complexes showing $\mathrm{Co}^{2+}>\mathrm{Ni}^{2+}>\mathrm{Fe}^{2+}>\mathrm{Mn}^{2+}$ while $\mathrm{M}^{3+}$ showed $\mathrm{Co}^{3+}>\mathrm{Fe}^{3+}>\mathrm{Mn}^{3+}>\mathrm{Cr}^{3+}$. $\mathrm{For}$ Tychophyton mantagrophytes the order was observed as $i$ $\mathrm{Co}^{2+}>\mathrm{Co}^{3+}>\mathrm{Ni}^{2+}>\mathrm{Fe}^{3+}>\mathrm{Fe}^{2+}>\mathrm{Cr}^{3+}>\mathrm{Mn}^{2+}>$ $\mathrm{Mn}^{3+}$, of which $\mathrm{M}^{2+}$ followed $\mathrm{Co}^{2+}>\mathrm{Ni}^{2+}>\mathrm{Fe}^{2+}>\mathrm{Mn}^{2+}$ and $\mathrm{M}^{3+}$ showed the trend $\mathrm{Co}^{3+}>\mathrm{Fe}^{3+}>\mathrm{Cr}^{3+}>\mathrm{Mn}^{3+}$. In general, it was observed that antifungal activity increased with decrease in ionic size.

Table 3. Antifungal activity of griesifulvin. , salicylic acid and the synthesized metal complexes

\begin{tabular}{lccccccc}
\hline S/N & Complex & $\begin{array}{c}\text { Aspergillus } \\
\text { ninger }(\mathrm{cm})\end{array}$ & $\%$ & $\begin{array}{c}\text { Aspergillus } \\
\text { hereus }(\mathrm{cm})\end{array}$ & $\%$ & $\begin{array}{c}\text { Trychophyton } \\
\text { mantagrophytes }(\mathrm{cm})\end{array}$ & $\%$ \\
\hline 1 & Griseofulvin & 5.00 & 100 & 5.00 & 100 & 5.00 & 100 \\
2 & Salicylic acid & 3.05 & 61 & 3.00 & 60 & 2.50 & 50 \\
3 & {$\left[\mathrm{Cr}(\mathrm{sal})_{3}\right]$} & 3.10 & 62 & 3.00 & 60 & 2.60 & 52 \\
4 & {$\left[\mathrm{Mn}(\mathrm{sal})_{2}\right]$} & 3.25 & 65 & 2.90 & 58 & 2.55 & 51 \\
5 & {$\left[\mathrm{Mn}(\mathrm{sal})_{3}\right]$} & 3.25 & 65 & 3.00 & 60 & 2.50 & 50 \\
6 & {$\left[\mathrm{Fe}(\mathrm{sal})_{2}\right]$} & 3.45 & 69 & 3.35 & 67 & 3.00 & 50 \\
7 & {$\left[\mathrm{Fe}(\mathrm{sal})_{3}\right]$} & 3.50 & 70 & 3.40 & 68 & 3.05 & 60 \\
8 & {$\left[\mathrm{Co}(\mathrm{sal})_{2}\right]$} & 3.55 & 71 & 3.60 & 72 & 3.30 & 61 \\
9 & {$\left[\mathrm{Co}(\mathrm{sal})_{3}\right]$} & 3.50 & 70 & 3.55 & 71 & 3.30 & 66 \\
10 & {$\left[\mathrm{Ni}(\mathrm{sal})_{2}\right]$} & 3.40 & 68 & 3.45 & 69 & 3.20 & 64 \\
\hline
\end{tabular}

The preliminary investigation of antimicrobial activities of the metal complexes in Table 3 revealed that the inhibitory ability of the metal complexes is notably higher than the ligand, though less than the compared standard antifungal drug, griesifulvin. And the actions against Aspergillus ninger and Aspergillus hereus are comparatively same but greater than that of Trychophyton mantagrophytes.

In all, the cobalt complexes showed the highest activity. However, whether this effect was due to the complex or the cobalt atom was not investigated. Furthermore, antimicrobial activity of the metal chelates can be explained on the basis of chelation theory which may enhance the biochemical potential of a bioactive species. This is because on chelation, the polarity of the metal ion will be reduced due to the overlap of the ligand orbital and partial sharing of the positive charge of the metal ion with donor groups and possibly $\pi$-electron delocalization over the whole molecule [19-21]. This may enhance the penetration of the complex into the lipid membranes enabling it to block the metal binding sites in the enzymes of micro-organisms. These 
complexes also disturb the respiratory processes of the cell and thus inhibit protein synthesis which restricts further growth of the organism.

\section{Conclusion}

Selected metal complexes of $M^{2+}$ and $M^{3+}$ were synthesized using salicylic acid and their antifungal activities were assessed. It was found that the complexes had antifungal activities against Aspergillus ninger, Aspergillus hereus, and Trychophyton mantagrophyte. This justified the use of transition metal complexes as therapeutic agents and as potential antibiotics.

\section{References}

[1] R. Shazia, I. Mohammed, N. Anwar, A. Haji, A. Amin, Transition metal complexes as as potential therapeutic agents, Academic journals.org BMBR, 5, 2010,38-45.

[2] K. Sanjay, S. Bharti, K. Singh, Metal based drugs: current use and future potential pharmaceutical chemistry Research lab. Department of pharmaceutics, institute of technology, Banaras Hundu Uni, India, 1(2), 39-51

[3] H. D. Revanasiddapa, B. Biyaya, L. K. Shiva, K. Shiva, Synthesis, Characterization and antimicrobial activity studies of some transition metals with desipramine, World Journal of Chem., 5(1), 2010, 18-25.

[4] K. O. Oguniran, K. O. Ajanaku, O. D.Ajani, C. O. Nwinyi, M. A. Alensela, Fe (III) and Co (III) complexes of mixed inhibitors, synthesis characterization and antimicrobial potential and their effect onalkaline phosphate activities of selected rat tissues, Journal of Physical Science, 3, 2008, 177-182.

[5] B. Alina, J. R.Anacona, Synthesis and characterization of metal complexes with ampicillin, Journal of coordination chemistry, 44, 1998, 173-182.

[6] D. G. James, J. S. Price, Field testing of methyl salicylate for recruitment and retention of beneficial insects in grapes and hops, J. Chem. Ecol., 30(8), 2004, 1613-1628.

[7] A. R. Shalita, comparison of salicylic acid and Benzoyl peroxide wash in the treatment of acne vulgaris, Clinical therapeutics, 2 1989, 267-268

[8] G. J. Pathel, M. V. Hathe, S. V. Patel, Synthesis, Characterization and chelating properties of benxozazolidin -2-one/4-aminosalicylic acid clubbed molecules, Electrochem. J. Chem., 3(13), 2006, 319-326.

[9] P. K. Patel, P. D. Petal, Synthesis, characterization, and metal complexation studies and biological screening of some newly synthesized metal complexes of 1-(4-carboxy-3-hydroxy-n-isopropyl amino methyl benzotriazole) with some transition metals, Int'l J.of Chem. Tech., 2(2), 2010, 1147-1152

[10] Y. Anyakulu, R. Prabhakara, Preparation, Charaterization and antimicrobial activity studies of some yearning complexes of Co (II) with acetylacetone and various salicylic acids, Electrochem. J. of Chem., 16(2), 1986, 257-272

[11] A. L. Ram, B. Shimita, L. Aka, K. S. Mehesh, B. Debjam, C. Smajeshi, D. Arjun, K. Arvind, Synthesis, Characterization and crystal structure of manganese (IV) complex derived from salicylic acid, Inorganic Chemical Acta, 8(1), 2006, 359

[12] S. S. Dube, S. S. Dhindsa, Composition and stability of some bivalent transition metal complexes of 3 , 5- dinitrosalicylic acid, Canadian Journal of Chemistry, 48, 1969, 243-245

[13] K. Gajendra, K. Dharmendra, D. Shima, K. Amid, J. Rajeev, Synthesis, Physical characterization and biological evaluation of Schiff base of $\mathrm{Cr}$ (III), Mn (III) and Fe (III) complexes, Electrochem. J. of Chem., 7(3), 2010,813-820

[14] N. Mahalakshmi, R. Rajavel, Binuclear Copper (II), Nickel (II), and Oxovanadium (IV) Schiff base complexes bearing $\mathrm{N}_{2} \mathrm{O}_{2}$ donors and their DNA cleavage and antimicrobial activity, Int'l J. of Pharm. and Technology, 2(4), 2010,1133-1157

[15] M. Imran, I. Iqbal, S. Iqbal, N. Ijaz, Invitro antibacterial studies of ciprofloxacin-imines and their complexes with $\mathrm{Cu}$ (II), Ni (II), Co (II), and Zn (II), Turkish J. of Biology, 31, 2007, 67-72

[16] K. H. Hemant, R. P. Ram Pal Chaudhary, Biological studies of a novel azo based heterocyclic Schiff base and its transition metal complexes, Pelagia Research library, Der Chemica Sinica, 1(2),2010,55-61

[17] A. P. Mishra, P. Gupta, Effect of chelation on therapeutic potency of drugs: Synthesis, structure, antimicrobial and insecticidal activity of $3 \mathrm{~d}$-metal complexes involving Schiff bases, J. of Chem. Phar. Research 3(2), 2011,150-161

[19] R. Shakru, N. J. P. Subhashini, J. Shivara, Synthesis, Characterzation, and antimicrobial studies onmixed ligand complexes of Co (II), Ni (II), and Cu (II) with isoxazole Schiff base and I, 10 -phenanthroline/ 2, 2'-bipyridine ligands, Hetero letters, 1(2), 2011, 166-175

[20] A. D. Kulkarni, S. A.Patil, P. S. Badami, Electrochemical properties of some transition metal complexes: synthesis, characterization ant invitro antimicrobial studies of $\mathrm{Co}$ (II), $\mathrm{Ni}$ (II), Cu (II), $\mathrm{Mn}$ (II) and $\mathrm{Fe}$ (III) complexes, Int'l J. of electrochem. Sci. 4, 2009, 717-729.

[21] L. Bin, L. Ying-Qi, Y. Bin-Sheng, H. Shu-Ping, Synthesis, Characterization and properties of Chromium (III) complex $\left[\mathrm{Cr}(\mathrm{SA})(\mathrm{en})_{2}\right] \mathrm{C} 1.2 \mathrm{H}_{2} \mathrm{O}$, J. of inorganic Biochem, 100, 2006,1462-1469. 